\section{Immunological detection of $\mathrm{m}$ - and $\mu$-calpains in the skeletal muscle of Marchigiana cattle}

\author{
E. Varricchio, ${ }^{1}$ M.G. Russolillo, ${ }^{2}$ \\ L. Maruccio, ${ }^{3}$ S. Velotto, ${ }^{4}$ G. Campanile, ${ }^{3}$ \\ M. Paolucci, ${ }^{1}$ F. Russo' \\ 'Department of Biological, Geological and \\ Environmental Sciences, University

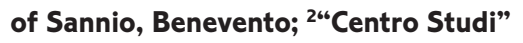 \\ Province of Benevento, University \\ of Sannio, Benevento; ${ }^{3}$ Department \\ of Veterinary Medicine and Animal \\ Productions, University Federico II \\ of Naples; ${ }^{4}$ Department of Soil, Plant, \\ Environment and Animal Production, \\ University Federico II of Naples, Italy
}

\section{Abstract}

Calpains are $\mathrm{Ca}^{2+}$-dependent proteases able to cleave a large number of proteins involved in many biological functions. Particularly, in skeletal muscle they are involved in meat tenderizing during post mortem storage. In this report we analyzed the presence and expression of $\mu$ - and m-calpains in two skeletal muscles of the Marchigiana cattle soon after slaughter, using immunocytochemical and immunohistochemical techniques, Western blotting analysis and Casein Zymography. Therefore, the presence and the activity of these proteases was investigated until $15^{\text {th }}$ day post mortem during normal process of meat tenderizing. The results showed $\mathrm{m}$ - and $\mu$-calpain immunosignals in the cytoplasm both along the $\mathrm{Z}$ disk/I band regions and in the form of intracellular stores. Moreover, the expression level of $\mu$-calpain but not m-calpain decreased after 10 days of storage. Such a decrease in $\mu$-calpain was accompanied by a gradual reduction of activity. On the contrary, m-calpain activity persisted up to 15 days of post mortem storage. Such data indicate that expression and activity of both $\mu$-calpain and m-calpain analyzed in the Marchigiana cattle persist longer than reported in literature for other bovines and may be related to both the type of muscle and breed examined.

\section{Introduction}

Calpains are a large family of intracellular cysteine proteases. To date, 14 members have been identified, which are expressed in an ubiquitous or tissue-specific manner., ${ }^{1,2}$ In skeletal muscle, the calpain system consists of three proteases, ubiquitously expressed iso- forms $\mu$-calpain, m-calpain, and p94 (or calpain 3$)$. The terms $\mu$-calpain and m-calpain refer to the micromolar $\mathrm{Ca}^{2+}$-requiring ( $\mu$-calpain) and millimolar $\mathrm{Ca}^{2+}$-requiring (m-calpain) proteases, respectively., Both proteases are heterodimers, each one composed of a 80 $\mathrm{kDa}$ catalytic subunit and a $28 \mathrm{kDa}$ regulatory subunit. The $28 \mathrm{kDa}$ subunit is identical in both the $\mu$ - and m-calpains. Both the $80 \mathrm{kDa}$ and the $28 \mathrm{kDa}$ subunits undergo auto-proteolysis from the N-terminus resulting in the conversion of the $80 \mathrm{kDa}$ subunit into a $76 \mathrm{kDa}$ form through a $78 \mathrm{kDa}$ intermediate. ${ }^{5}$ In both $\mu$ - and m-calpains the $80 \mathrm{kDa}$ subunit is divided into four domains based on the amino acid sequence: domain I or $\mathrm{NH}_{2}$-terminal domain; domain II; domain III that contains two potential EF-hand $\mathrm{Ca}^{2+}$ binding sequences, one at the domain I//II boundary and one at the domain III/IV boundary; and domain IV which contains four sets of sequences that predict EF-hand $\mathrm{Ca}^{2+}$ binding sites. ${ }^{2}$ Associated with the calpain proteolytic enzyme family is the calpain-specific endogenous inhibitor, calpastatin. ${ }^{1,6}$ Calpastatin contains 4 inhibitory domains, each one capable of inhibiting calpain activity.

Recently, some research groups have identified calpastatin genes polymorphism and have shown that some of them are predictive of carcass quality in cattle and in pigs. ${ }^{7-9}$ Additionally, there are markers within the calpastatin and $\mu$-calpain genes that are able to identifying beef cattle with the genetic potential to produce tender meat. ${ }^{10,11}$ The calpaincalpastatin system has different yet crucial roles in the cell. During embryo development, the knockout of both $\mu$ - and m-calpain is lethal. ${ }^{11,12}$ Such proteases are able to cleave a large number of proteins both in vitro and in vivo. They act on cytoskeletal proteins, especially those involved in cytoskeletal/plasma membrane interactions, ${ }^{13-17}$ on some transcription factors ${ }^{18-21}$ and so they are involved in the cell cycle, ${ }^{22-24}$ regulation of gene expression ${ }^{25-27}$ and apoptosis. ${ }^{28-32}$ Particularly, the calpainscalpastatin system brings about cytoskeletal damage and membrane disruption in muscle cells. In this manner, it is involved in the pathogenetic mechanism of muscular dystrophy ${ }^{33,34}$ in living animals and in meat tenderness. $^{35}$

In striated muscles, after death, the calpains rapidly cleave titin and nebulin at sites near the Z-disk, thereby severing their attachment to the proteins in the Z-disk. In addition, the calpains cleave the intermediate filament protein desmin that attaches the Z-disk to the sarcolemma; hence, the proteins constituting $\mathrm{Z}$ disk, including $\alpha$-actinin, are released, and the Z-disk disappears leaving a space in the myofibril. ${ }^{1,36,37}$ The calpains also rapidly cleave $\mathrm{T}$ and I troponins and tropomyosin, and C-protein, ${ }^{36-38}$ which contribute to the stability of the thin and thick filaments, respectively. Calpains
Correspondence: Dr. Finizia Russo, Department of Biological, Geological and Environmental Sciences, University of Sannio, via Port'Arsa 11, 82100 Benevento, Italy.

Tel. +39.0824.305163 - Fax: +39.0824.23013.

E-mail: finiziarusso@libero.it

Key words: m-calpain, $\mu$-calpain, skeletal muscle, Marchigiana cattle, immunohistochemistry, electron microscopy.

Received for publication: 17 January 2012.

Accepted for publication: 14 November 2012.

This work is licensed under a Creative Commons Attribution NonCommercial 3.0 License (CC BYNC 3.0).

\section{(C) Copyright E. Varricchio et al., 2013}

Licensee PAGEPress, Italy

European Journal of Histochemistry 2013; 57:e2 doi:10.4081/ejh.2013.e2

cleave myosin and actin, the two major proteins in striated muscle, very slowly, if at all. ${ }^{39}$ Some ultrastructural analyses reveal $\mu$-calpain immunoreactivity in the bovine skeletal muscle within sarcomeres, essentially at the center of the I-band and at the periphery of Z-lines, ${ }^{40}$ where it co-localize with myotilin, an alphaactinin, gamma filamin binding protein found in the Z-band edges. In the bovine skeletal muscle induced by conditioning and high-pressure treatment, the calpain localization was two times greater in both the I-band/Z-disk and A-band in the muscle immediately after thawing than after 7 days. ${ }^{41}$ In light of the crucial role played by calpains on meat tenderness, the aim of this study was to analyze the presence and expression of $\mu$ - and $\mathrm{m}$ - calpains in the skeletal muscle of the Marchigiana cattle soon after slaughter and during aging, using immunocytochemical and immunohistochemical techniques and Western blotting analysis. Moreover, Casein Zymography was performed to consider the proteolitic activity of $\mu$ - and $\mathrm{m}$ calpain during aging in the skeletal muscle of this cattle breed.

For this study, we have chosen the Marchigiana cattle for its commercial interest and meat quality. The meat of this animal is a PGI (Protected Geographical Indication) product and the name of the trade mark is Vitellone Bianco dell'Appennino Centrale.

\section{Materials and Methods}

\section{Animals and tissue preparation}

Samples of masseter and diaphragm muscles were collected from ten males 24-monthold Marchigiana cattle obtained from a local slaughterhouse (Campolattaro, Benevento, Italy). The animals were born and farmed in 
the province of Benevento (Italy) and their meat was intended for human consumption. Sampling was made immediately after death. Cubic fragments of $1 \mathrm{~cm}$ of length underwent different treatments for immunohistochemistry and scanning electron microscopy (SEM) analysis. For immunohistochemistry, muscle samples were submerged in 2-metilbutane, extra pure (Acros Organics, NJ, USA) for $5 \mathrm{sec}$ onds and then frozen in liquid nitrogen before being cut at the cryostat. For immunogoldlabeling SEM analysis, specimens were submerged in PBS for $1 \mathrm{~h}$ at room temperature (RT). Additional muscle samples were stored at $4^{\circ} \mathrm{C}$, collected and frozen $\left(-80^{\circ} \mathrm{C}\right)$ at $0,5,10$ and 15 days post-mortem for Western blotting analysis and Casein Zymography.

\section{Immunohistochemistry}

Frozen samples of masseter and diaphragm muscles were serially cut at a cryostat in transversal and longitudinal sections of $10 \mu \mathrm{m}$. After blocking endogenous peroxidase activity with $0,3 \%$ hydrogen peroxide for $20 \mathrm{~min}$ at RT, the sections were rinsed in $0.01 \mathrm{M}$ phosphate buffered saline (PBS), pH 7.4, for $15 \mathrm{~min}$. Primary antibodies were monoclonal antibodies raised in mouse against the domain III/IV of m-calpain (C-268; Sigma, Sant Louis, MO, USA) and polyclonal antibodies raised in rabbit against domain IV of $\mu$-calpain (C-5611; Sigma). Primary antibodies were diluted 1:50 and applied on the sections overnight in a moist dark chamber at $4^{\circ} \mathrm{C}$. The other components of the immunological reaction were contained in the Envision Dako (K4006, DakoCytomation, Glostrup, Denmark) employed with mouse antibodies and Vectastain Elite ABC Kit (PK-6101; Vector Laboratories Inc., Burlingame, CA, USA) employed with rabbit antibodies. The final staining was performed using a solution of 3-3' diaminobenzidine tetrahydrocloride (DAB; Sigma) of $10 \mathrm{mg}$ in $15 \mathrm{~mL} \mathrm{0.5M}$ Tris buffer, $\mathrm{pH}$ 7.6 , containing $0.03 \%$ hydrogen peroxide. The images of the immunostainings were acquired and photographed using the microscope Leica DMRA2 (Leica, Wetzlar, Germany) equipped with a DC300F digital camera.

Negative controls were obtained substituting the primary antisera with PBS or normal serum in the specific step, or alternatively, by absorbing each primary antiserum with an excess of the relative peptide (100 $\mu$ g of peptide/mL of diluted antiserum).

\section{Immunogold-labeling SEM analysis}

Samples were incubated for $2 \mathrm{~h}$ in a solution containing normal goat serum (900.077; Aurion, Wageningen, The Netherlands) diluted 1:10 in PBS, and then incubated with primary monoclonal antibodies raised in mouse against the domain II//IV of m-calpain (C-268; Sigma) and primary polyclonal antibodies raised in rabbit against the domain IV of $\mu$-calpain (C-5611; Sigma), diluted 1:50 in PBS, overnight at $4^{\circ} \mathrm{C}$. After washing in PBS, the samples were incubated with gold-conjugated goat anti-mouse IgG (806.022, Aurion) and goat anti rabbit IgG (106.011, Aurion) diluted 1:200 in PBS for $1 \mathrm{~h}$ at RT. The secondary antibody was conjugated with gold particles of different sizes ( 5 and $15 \mathrm{~nm}$ ). After washings in PBS, samples were fixed in $2.5 \%$ glutaraldehyde in $0.1 \mathrm{M}$ Cacodylate buffer, at $\mathrm{pH} 7.2$, for 30 min. After washings with distilled water, samples were subjected to silver enhancement (500.055, Aurion). The silver enhancement process enables the use of antibodies conjugated with small $(6 \mathrm{~nm})$ gold particles allowing fast penetration and high labeling efficiency. ${ }^{42}$ Samples were then dehydrated through an ethanol series and dried to the critical point The specimens, mounted on stubs, were examined under a LEO 435 VP scanning electron microscope at variable pressure (80-120 Pa) in the backscattered electron mode, which allows the detection of gold particles associated with cells even if they are located intracellularly. ${ }^{43}$

Since the samples were not coated by gold, only conjugated gold deriving from immunocytochemical reaction was observed by SEM and photographed.

\section{Western blot analysis}

Proteins from masseter and diaphragm muscle samples were extracted with Lysis buffer $(220 \mathrm{mM}$ D-Mannitol, $70 \mathrm{mM}$ Saccharose, $1 \mathrm{mM}$ EDTA, $20 \mathrm{mM}$ Tris pH 7.4, containing protein inhibitors $2 \mathrm{mM}$ PMSF, 1 $\mathrm{mM}$ pepstatin A, $2 \mathrm{mM}$ trypsin inhibitor from chicken egg white). Muscle samples were homogenized with ultra-turrax T25 (IKAlabortechnik, Staufen, Germany) for three times at $500 \mathrm{rpm}, 800 \mathrm{rpm}$ and 14,000 rpm for $10 \mathrm{~min} / \mathrm{each}$. The supernatants were collected and underwent protein determination with the Bio-Rad dye protein assay (Bio-Rad laboratories Inc., UK). Samples were boiled at $98^{\circ} \mathrm{C}$ for $10 \mathrm{~min}$ in loading buffer $(50 \mathrm{mM}$ tris $\mathrm{HCl} \mathrm{pH}$ 6.8, $100 \mathrm{mM} \beta$-mercaptaethanol, $2 \%$ SDS, 0,1\% blue bromophenol, $10 \%$ glycerol). The proteins were separated on a $8 \%$ SDS-polyacrylamide gel electrophoresis with $4 \%$ stacking gel in $1 \%$ Tris-glycine buffer (0.025 M Tris, $0.192 \mathrm{M}$ glycine, and 0.1\% SDS pH 8.3) in a miniprotean cell (Bio-Rad) at 130 volts for $2 \mathrm{~h}$. The separated proteins were electro transferred onto a nitrocellulose membrane with transfer buffer ( $39 \mathrm{mM}$ Tris base, $0.2 \mathrm{M}$ glycine, and $20 \%$ methanol $\mathrm{pH} 8.5$ ) in a minitransfer cell (Bio- Rad) at 100 volts at $4^{\circ} \mathrm{C}$ for $2 \mathrm{~h}$. Membranes were incubated at $4^{\circ} \mathrm{C}$ for $1 \mathrm{~h}$ in blocking buffer containing 1\%PBS, $0.05 \%$ Tween 20 and $5 \%$ dried non-fat milk and with monoclonal antibodies raised in mouse against domain III/IV of m-calpain (C-268; Sigma) and monoclonal antibodies against $\beta$ - actin (A5441, Sigma) as an internal marker, and with polyclonal antibodies raised in rabbit against domain IV of $\mu$-calpain (C-5611; Sigma) and polyclonal antibodies against $\beta$ actin (A5060, Sigma) as an internal marker over night at $4^{\circ} \mathrm{C}$. Primary antibodies were diluted 1:1000. The incubation with secondary anti-mouse and anti-rabbit IgG (1:5000) was carried out for $1 \mathrm{~h}$ at RT. Signals were detected by chemiluminescence with the Immobilan Western Chemiluminescent HRP substrate Kit (Millipore, Billerica, MA, USA) with Chemidoc (Bio-Rad). A prestained molecular-weight ladder (Novex Sharp protein standard, LC5800, Invitrogen, Hilden, Germany) was used to determine protein size. Western blotting bands were quantified by Quantity One (Bio-Rad) software. Rat skeletal muscle was used as a positive control.

\section{Statistical analysis}

Data were analyzed by one-way analysis of variance (ANOVA) and Turkey's test. The analysis were carried out with the Statistica version 7.0 statistical package (Statsoft inc., Tulsa, OK, USA). Data are expressed as mean \pm SEM

\section{Casein zymography method}

To determine activity of $\mu$ - and $\mathrm{m}$ - calpain the casein zymography method based on the protocol described by Raser, Posner, and $W{ }^{4}{ }^{44}$ was used. One gram of each sample was homogenized with ultra-turrax T25 $(13.500 \mathrm{rpm})$ in $6 \mathrm{~mL}$ of extraction buffer (50 mM Tris; 5 mM EDTA; $10 \mathrm{mM}$ Monothio glycerol; one tablet per $50 \mathrm{~mL}$ of Protease Inhibitor Cocktail Tablet COMPLETE, RAS Roche Applied Science, Mannheim, Germany; $\mathrm{pH} \mathrm{8.0)}$ and centrifuged for $30 \mathrm{~min}$ a $4^{\circ} \mathrm{C}$ and $15,000 \mathrm{~g}$. Each sample was run using 12,5\% casein precast gel (Bio-Rad Laboratories, Hercules, CA) twenty-five $\mu \mathrm{L}$ of sample buffer (300 mM Tris, 40\% glycerol, 0,02\% bromophenol blue, $100 \mathrm{mM}$ DTT, pH 6.8) were added to $75 \mu \mathrm{L}$ of the supernatant and $15 \mu \mathrm{L}$ sample were loaded into each well of the gel. Before loading the samples, the gel was prerun for 15 min at $80 \mathrm{~V}$ (running buffer: $25 \mathrm{mM}$ Tris, 192 mM glycine, 1 mM EDTA, pH 8.3).

Electrophoresis was carried out at $80 \mathrm{~V}$ for 3 $\mathrm{h}$ at $4^{\circ} \mathrm{C}$. Gels were then removed, rinsed with deionized $\mathrm{H}_{2} \mathrm{O}$, and incubated with shaking at RT in $100 \mathrm{~mL}$ of incubation buffer $(50 \mathrm{mM}$ Tris, $4 \mathrm{mM} \mathrm{CaCl}_{2}, 10 \mathrm{mM}$ monothioglycerol, $\mathrm{pH}$ 7.5) for $1 \mathrm{~h}$; gels were rinsed twice. The calpain activity was stopped by washing the gel overnight with shaking, using $20 \mathrm{mM}$ Tris, 10 mM EDTA, pH 7.0. Gels were stained for $6 \mathrm{~h}$ with colloidal Comassie Brilliant Blue $\mathrm{G}^{45}$ and destained overnight with deionized $\mathrm{H}_{2} \mathrm{O}$. Signals were detected by UV transillumination with Chemidoc (Bio-Rad). 


\section{Results}

Since the results obtained for both masseter and diaphragm muscles were similar, we will refer to them as the skeletal muscles of Marchigiana cattle.

\section{Immunohistochemistry}

In the longitudinal sections of the skeletal muscle of Marchigiana cattle, both $\mathrm{m}$ - and $\mu$ - calpain immunopositivity could be seen (Figure 1a,b). The positivity was present for both calpains along $\mathrm{Z}$ disk/I band regions. In the A-band area the positivity was absent (Figure 1a,b).

\section{Immunogold-labeling SEM analysis}

Both $\mathrm{m}$ - and $\mu$-calpain immunoreactive gold particles were detected in the cytoplasm (Figure 2). In particular, immunopositivity was localized along the $\mathrm{Z}$ disk/I band regions (Figure 2a,b) and in the intracellular stores (Figure 2c,d).

\section{Western blot analysis}

The espression of m- (Figure 3a) and $\mu$-cal-
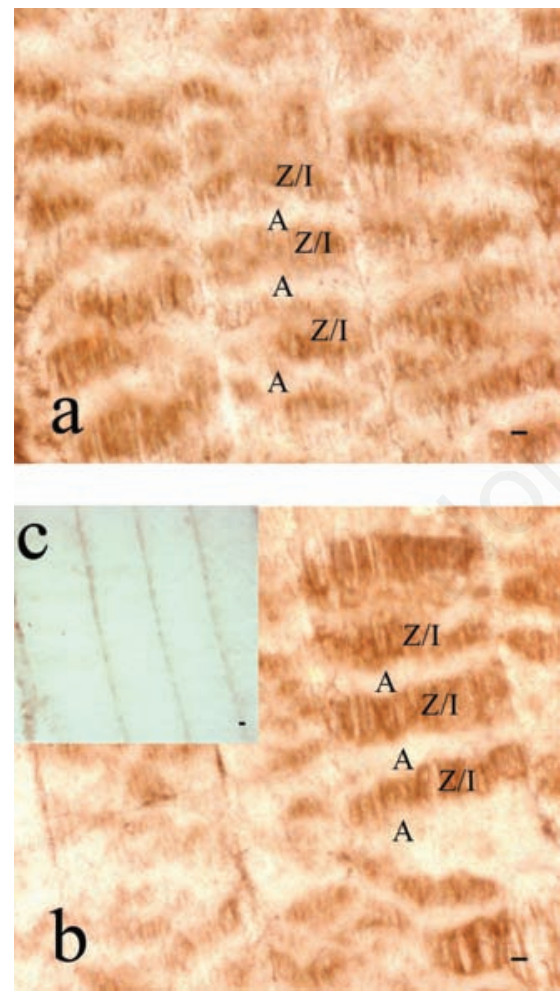

Figure 1. Immunohistochemistry: longitudinal sections of Marchigiana cattle messeter (a) and diaphragm (b) muscles. m- (a) and $\mu$-(b) calpain immunopositivity was identified in the $\mathrm{Z}$ disk/I band region (Z/I), while the positivity was absent in the Aband area (A). Negative control (c). Scale bars: $10 \mu \mathrm{m}$. pains (Figure 3b) was detected at 0, 5, 10 and 15 days of storage at $4^{\circ} \mathrm{C}$ in the masseter (Figure 3a) and diaphragm (Figure $3 \mathrm{~b}$ ) muscles. Both $\mathrm{m}$ - and $\mu$-calpains showed a molecular mass of about $80 \mathrm{kDa}$. A significant decrease in the level of expression for $\mu$-calpain was detected at the $10^{\text {th }}$ and the $15^{\text {th }}$ day (Figure 3b); m-calpain showed a significant decrease at the $15^{\text {th }}$ day (Figure $3 \mathrm{~b}$ ). Densitometric analysis of the immunoreactive bands was performed and $\beta$-actin (molecular mass of about $42 \mathrm{kDa}$ ), as an internal marker, was used to normalize the optical density.

\section{Casein zimography}

Four bands of enzymatic activity were identified on the gels. Two of these bands were located on the top of the gels, where $\mu$-calpain normally is positioned; the other two migrated further into gels, where m-calpain runs. ${ }^{44,46} \mathrm{We}$ assumed that the two bands located on top of the gels corresponded to native and autolyzed $\mu$-calpain activities (Figure 4, thin arrow), and the other two bands represent native and autolyzed m-calpain activities (Figure 4, thick arrow). The autolyzed forms of both $\mu$ - and $\mathrm{m}$ calpain migrated slightly faster than the native forms.
Therefore, autolyzed $\mu$-calpain migrated at a position in between native $\mu$-calpain and native m-calpain. ${ }^{47}$ During the post-mortem storage we observed a gradual reduction of native and autolyzed $\mu$-calpain activities while native and autolyzed m-calpain activities persisted up to 15 days (Figure 4).

\section{Controls}

Negative controls did not show specific immunostaining. Moreover, the incubation of $\mathrm{m}$-and $\mu$-calpain antiserum preincubated with its homologous antigen showed no immunoreactivity. In Western blotting analysis, rat skeletal muscle, used as a positive control, showed a band of about $80 \mathrm{kDa}$ when antibodies against $\mathrm{m}$ - and $\mu$-calpains were employed (Figure 3a,b).

\section{Discussion}

In this study, we report on the presence, level of expression and enzymatic activity of $m$ - and $\mu$-calpain in the masseter and diaphragm muscle of Marchigiana cattle.
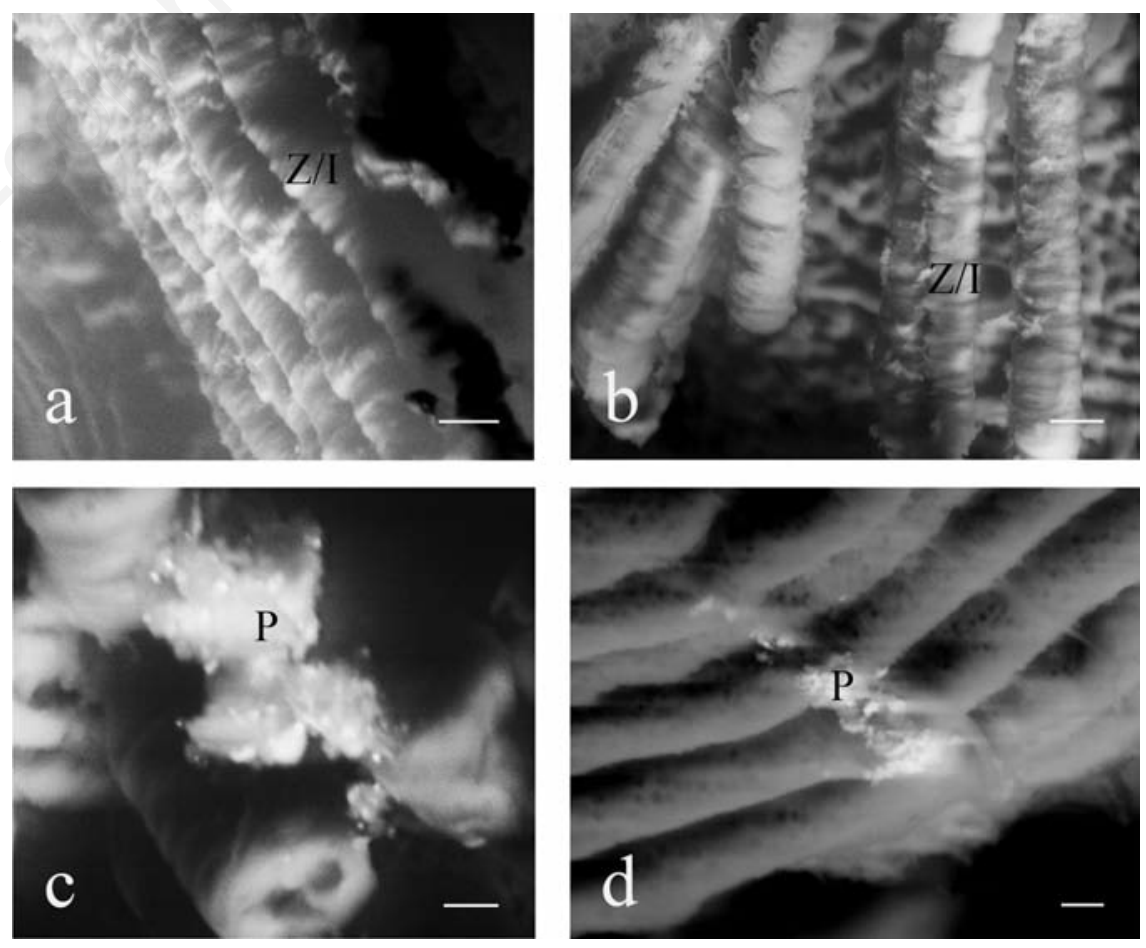

Figure 2. Immunogold labeling/SEM analysis: $m-(a, c)$ and $\mu-(b, d)$ calpain immunoreactive gold particles localized in $\mathrm{Z}$ disk/I band region $(\mathrm{Z} / \mathrm{I})(\mathrm{a}, \mathrm{b})$ and in the intracellular stores $(P)(c, d)$ in the masseter muscle. Scale bars a,b: $30 \mu \mathrm{m}$; scale bars c,d: $10 \mu \mathrm{m}$. 
Immunohistrochemistry and immunogoldlabeling SEM analysis revealed the presence of calpains both along the $\mathrm{Z}$ disk/I band areas and in intracellular stores. These results are in agreement with the current literature. In fact, in normal skeletal muscle the majority of calpains are located on or next to the Z-disk with few in correspondence to the I-band and very few in correspondence to the A-band, as well as in vesicles and subcellular organelles. ${ }^{36,48-51}$ Particularly, during the first few hours postmortem, $\mathrm{m}$ - and $\mu$-calpains are localized in subcellular organelles in the inner sarcoplasm, and then spread along $\mathrm{Z}$ disk/I-band areas of myofibrils beginning the transformation of muscle into meat.

The presence of $\mathrm{m}$-and $\mu$-calpains in correspondence to the $\mathrm{Z}$ disk/I band areas of the diaphragm and masseter muscles of Marchigiana cattle suggests that in these muscles the proteolytic action of calpains occurs on those proteins that are involved in keeping miofilaments attached to the myofibril. In fact, calpains rapidly cleave titin and nebulin at the point where these 2 polypeptides enter the $\mathrm{Z}$ disk. $^{2}$ Titin and nebulin cleavage, together with that of desmin and filamin, release $\alpha$ actinin, ${ }^{52}$ the principal $Z$ disk protein, from the myofibril. Calpains do not degrade at all or degrade very slowly, actin and myosin, $, 36,51,52$ the two major proteins in skeletal muscle myofibrils, implying that calpains had a limited and very specific subsite specificity. ${ }^{36}$ Calpains also degrade $\mathrm{M}$ proteins, tropomyosin and troponin, albeit at slower rates than titin and nebulin. ${ }^{51,53}$ In general, calpains cleave proteins at a limited number of sites and produce large polypeptide fragments rather than small peptides or amino acids. ${ }^{51,53,54}$ Because of the limited specificity of the calpains, further degradation of myofibril proteins in aminoacids requires the participation of other proteases. It seems likely that the proteasome plays a major role in the degradation and release of actin, myosin and the other myofibrillar protein fragments. ${ }^{55-57}$ The proteosome, on the other hand, cannot degrade intact myofibrils ${ }^{58}$ or cytoskeletal complexes, likely because the entrance to the central cavity of the proteosome containing the active sites is only 19-13 $\AA$ in diameter and is much too narrow to allow entry of myofibrils that range from 10 to $100 \mu \mathrm{m}$ in diameter. Therefore, the calpains begin the process of muscle transformation in meat that in turn, requires other proteases to be completed. Among these, the caspase system could be active post-mortem and contribute to tenderization ${ }^{9,59,60}$ throughout an interaction with the calpain system. In fact, caspases may contribute to decrease the calpastatin level in the muscle aging and this, in turn, could results in the activation of calpains and thus reducing toughness. ${ }^{9,61}$

In the skeletal muscle of Marchigiana cattle the level of expression of $\mathrm{m}$ - and $\mu$-calpains a

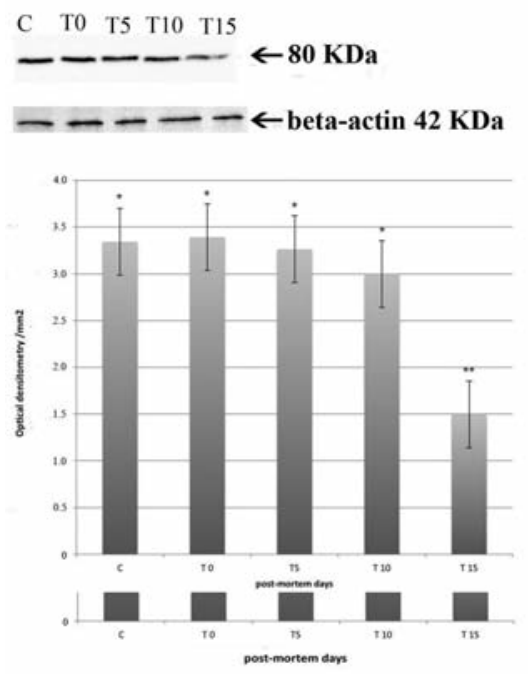

b

C T0 T5 T10 T15

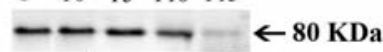

$=-\infty \leftarrow$ beta-actin 42 KDa

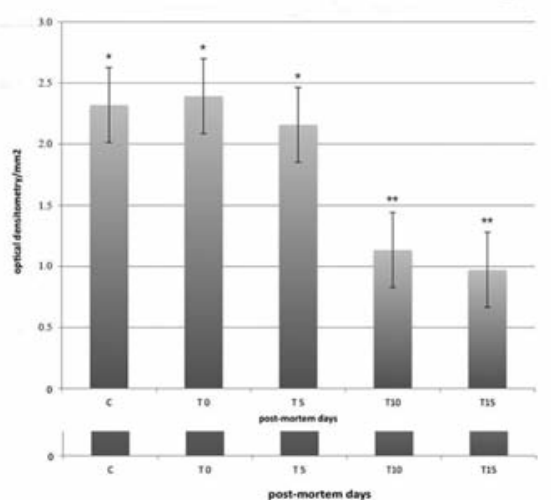

Figure 3. Upper: Western blotting analysis carried out on masseter (blot-a) and diaphragm (blot-b) muscles. The detected $\mathrm{m}$ - (blot-a) and $\mu$ - (blot-b) calpains showed a molecular mass of $80 \mathrm{kDa}$. $\beta$-actin showed a molecular mass of $42 \mathrm{kDa}$ (blot a,b). $\mathrm{C}=$ control (rat skeletal muscle); $\mathrm{T} 0=$ soon after animals slaughter; $\mathrm{T} 5=5$ th day postmortem (p.m.) storage; $\mathrm{T} 10=10^{\text {th }}$ day post mortem storage; $\mathrm{T} 15=15^{\text {th }}$ day post-mortem storage. Down: densitometric analysis of the immunoreactive bands. Each value represents the mean \pm SEM of ten independent experiments. Asterisks indicate statistically significant differences $(P<0.05)$.

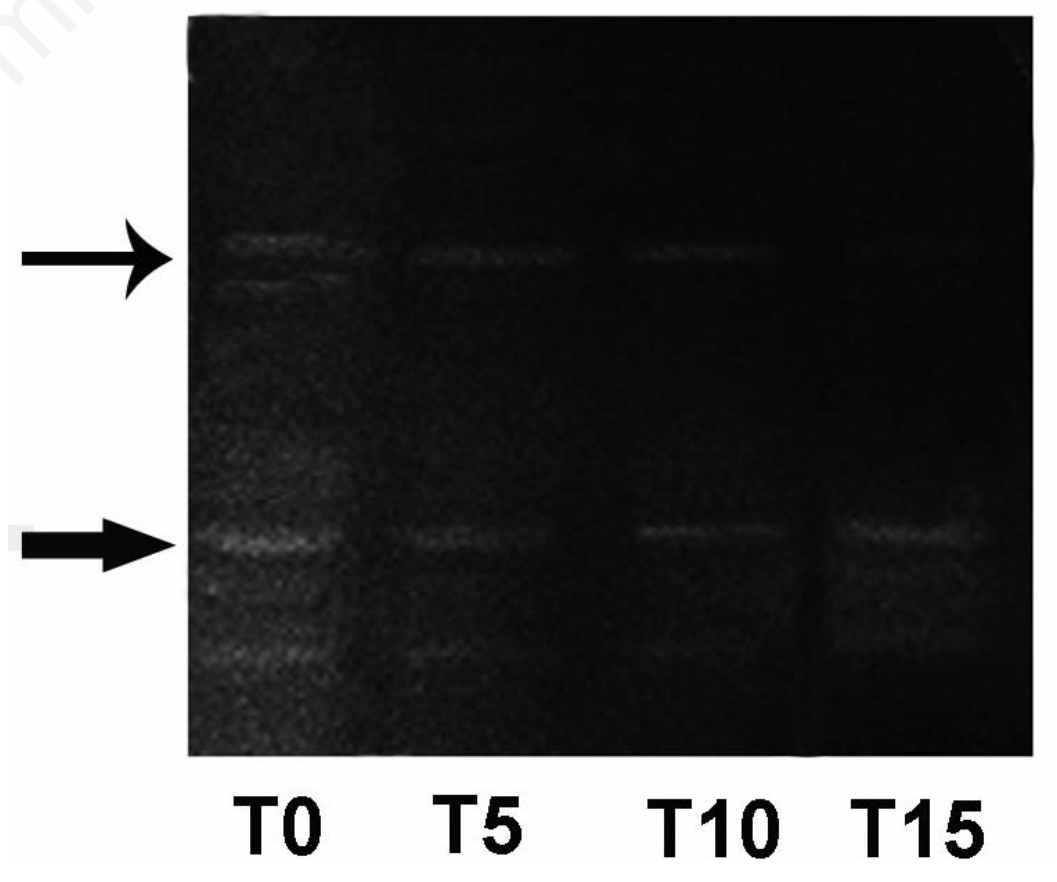

Figure 4. Top: native and autolyzed $\mu$-calpain activities (thin arrow). Down: native and autolyzed $\mathrm{m}$-calpain activities (thick arrow). $\mathrm{T} 0=$ soon after animals slaughter; $\mathrm{T} 5=5^{\text {th }}$ day post-mortem (p.m.) storage; $\mathrm{T} 10=10^{\text {th }}$ day post-mortem storage; $\mathrm{T} 15=15^{\text {th }}$ day post-mortem storage. 
and their enzymatic activity was detected up to 15 days post-mortem. Our results indicate a decrease in the level of expression of $\mu$-calpain after 10 days of storage, while m-calpain expression persisted up to 15 days of postmortem storage. The trend of activity of both $\mu-$ and m-calpain overlap with their expression pattern. It is well known that post mortem activation of m-calpain is due to the increasing concentration of $\mathrm{Ca}^{2+} .28$ The activity of $\mu$ - and m-calpain is synergistic: $\mu$-calpain contributes to early post-mortem proteolysis, while m-calpain is partially activated and contributes to tenderization during prolonged ageing. ${ }^{35,62-64} \mathrm{In}$ the bovine skeletal muscles (longissimus dorsi, semimembranosus, triceps brachii and psoas major), the proteolytic activity of $\mu$-calpain decreases rapidly during post mortem storage and very little activity can be detected after 48 $\mathrm{h}$ post-mortem storage at $4^{\circ} \mathrm{C}$, so that only 10 to $20 \%$ of m-calpain activity remained after $144 \mathrm{~h}$ post-mortem. ${ }^{47,65}$ The proteolitic activity of calpains depends on the $\mathrm{Ca}^{2+}$ concentration and $\mathrm{pH}$ of the muscle during the post mortem storage. ${ }^{47,66,67}$ We choose, as muscle samples, the diaphragm and the masseter muscle because, in live animals, they are striated muscles subjected to mechanical and functional stresses during breathing (diaphragm muscle) and chewing (masseter muscle). By histoenzymatic staining, these muscles show a prevalence of oxidative fibers rather than glycolityc ones (data not shown) that could lead a slower lowering of the $\mathrm{pH}$ in the post-mortem storage and explain the slower trend of activity and expression of both $\mu$ - and m-calpain reported here.

Our results are in agreement with the picture emerging from previous researches, although we reveal a greater persistence of expression and enzymatic activity of $\mathrm{m}$ - and $\mu-$ calpains in Marchigiana cattle skeletal muscle. Such disagreement could be ascribed to the type of muscle chosen or to the breed considered for this study. Certainly, further investigations, involving, also, ultrastructural analysis, may help to study the role of calpains in meat tenderness in the Marchigiana cattle.

\section{References}

1. Dayton WR, Reville WJ, Goll DE, Stromer MH. A $\mathrm{Ca}^{2+}$-activated protease possibly involved in myofibrillar protein turnover. Partial characterization of the purified enzyme. Biochemistry 1976;15:2159-67.

2. Goll DE, Thompson VF, Li H, Wei W, Cong J. The calpain system. Physiol Rev 2003; 83:731-801.

3. Cong JY, Goll DE, Peterson AM, Kapprell HP. The role of autolysis in activity of the $\mathrm{Ca}^{2+}$-dependent proteinases ( $\mu$-calpain and m-calpain). J Biol Chem 1989; 264: 10096-103.
4. Suzuki K. Nomenclature of calcium dependent proteinase. Biomed Biochim Acta 1991;50:483-4.

5. Zimmerman UJP and Schlaepfer WW. Two stage autolysis of the catalytic subunit initiates activation of calpain I. Biochim Biophys Acta 1991;1078:192-8.

6. Wendt A, Thompson VF, Goll DE Interaction of calpastatin with calpain: a review. Biol Chem. 2004;385:465-72.

7. Barendse WJ. DBA markers for meat tenderness. International patent application PCT/AU02/00122. International patent publication WO 02/064820A1.

8. Cionabu DC, Bastiaansen JWM, Lonergan SM, Thomsen H, Dekkers JCM, Plastow GS, et al. New alleles in calpastatin gene are associated with meat quality traits in pigs. J Anim Sci. 2004;82:2829-39.

9. Kemp CM, Sensky PL, Bardsley RG, Buttery PJ, Parr T. Tenderness - An enzymatic view. Meat Sci 2010;84:248-56.

10. Casas E, White SN, Wheeler TL, Shackelford SD, Koohmaraie M, Riley DG, et al. Effects of calpastatin and $\mu$-calpain markers in beef cattle on tenderness traits. J Anim Sci 2006;84:520-5.

11. Gruber SL, Tatum JD, Engle TE, Chapman PL, Enns RM, Belk KE, et al. Effects of genetic markers and implant strategy on longissimus and gluteus muscle tenderness of calf-fed steers and heifers. J Anim Sci 2011;89:1401-11.

12. Arthur JSC, Elce JS, Hegadorn C, Williams $\mathrm{K}$, Greer PA. Disruption of the murine calpain small subunit gene, Capn4: calpain is essential for embryonic development but not for cell growth and division. Mol Cell Biol 2000;20:4474-81.

13. Zimmerman UJP, Boring L, Pak JH, Mukerjee N, Wang KK. The calpain small subunit is essential: its inactivation results in embryonic lethality. Iubmb Life 2000;50:63-8.

14. Dayton WR, Goll DE, Stromer MH, Reville WJ, Zeece MG, Robson RM. Some properties of a $\mathrm{Ca}^{2+}$-activated protease that may be involved in myofibrillar protein turnover. In: Reich E, Rifkin DB and Shaw E (eds.) Cold Spring Harbor Conferences on Cell Proliferation. Proteases and Biological Control. Cold Spring Harbor, NY: Cold Spring Harbor Laboratory; 1975, p. 551-77.

15. Billger M, Wallin M, Karlsson J0 Proteolysis of tubulin and microtubuleassociated proteins 1 and 2 by calpain I and II. Difference in sensitivity of assembled and disassembled microtubules. Cell Calcium 1988;9:33-44.

16. Croall DE, De Martino, GN. Calcium-activated neutral protease (calpain) systems structure, function, and regulation. Physiol Rev 1991;71:813-47.

17. Suzuki A, Kim K, Ikeuchi Y. Proteolytic cleavage of connectin/titin. Adv Biophys 1996;33:53-64.

18. Glading A, Lauffenburger DA, Wells A. Cutting to the chase: calpain proteases in cell motility. Trends Cell Biol 2002;12:4654.

19. Kishimoto A, Mikawa K, Hashimoto K, Yasuka I, Tanaka S, Tominaga M, et al. Limited proteolysis of protein kinase $\mathrm{C}$ subspecies by calcium-dependent neutral protease (calpain). J Biol Chem 1989;264: 4088-92.

20. Gregoriou M, Willis AC, Pearson MA, Crawford $\mathrm{C}$. The calpain cleavage sites in the epidermal growth factor receptor kinase domain. Eur J Biochem 1994;223: $455-64$.

21. Norris FA, Atkins RC, Majerus PW. Inositol polyphosphate 4-phosphatase is inactivated by calpain-mediated cleavage in stimulated human platelets. J Biol Chem 1997; 272:10987-9.

22. Schoenwaelder SM, Burridge K. Evidence for a calpeptin sensitive protein-tyrosine phosphatase upstream of the small GTPase Rho. A novel role for the calpain inhibitor calpeptin in the inhibition of protein-tyrosine phosphatases. J Biol Chem 1999;274:14359-67.

23. Choi YH, Lee SJ, Nguyen PM, Jang JS, Lee J, Wu M-L, et al. Regulation of cyclin D1 by calpain protease. J Biol Chem 1997;272: 28479-84.

24. Zhang W, Lu Q, Xie Z-J, Mellgren RL. Inhibition of the growth of WI-38 fibroblasts by benzyloxycarbonyl-Leu-Leu-Tyr diazomethyl ketone: evidence that cleavage of p53 by a calpain-like protease is necessary for G1 to S-phase transition. Oncogene 1997;14:55-63.

25. Xu Y, Mellgren RL. Calpain inhibition decreases the growth rate of mammalian cell colonies. J Biol Chem 2002;277:2147479.

26. Gonen H, Shkedy D, Barnoy S, Kosower NS, Ciechanover A. On the involvement of calpains in the degradation of the tumor suppressor protein p53. FEBS Lett 1997; 406:17-22.

27. Kubbutat MHG, Voesden KH. Proteolytic cleavage of human $p 53$ by calpain-a potential regulator of protein stability. Mol Cell Biol 1997;17:460-8.

28. Pariat M, Carillo S, Molinari M, Salvat C, Debussche L, Bracco L, et al. Proteolysis by calpains: a possible contribution to degradation of p53. Mol Cell Biol 1997;17:280615.

29. Schollmeyer JE. Role of $\mathrm{Ca}^{2+}$ and $\mathrm{Ca}^{2+}$-activated protease in myoblast fusion. Exp Cell Res 1986;162:411-22.

30. Chi X-J, Hiwasa T, Maki M, Sugaya S, Nomura J, Kita K, et al. Suppression of okadaic acid-induced apoptosis by overexpression of calpastatin in human UVr-1 
cells. FEBS Lett 1999;459:391-4.

31. Squier MKT, Sehert AJ, Sellins KS, Malkinson AM, Takano E, Cohen JJ. Calpain and calpastatin regulate neutrophil apoptosis. J Cell Physiol 1999;178: 311-19.

32. Lu T, Xu Y, Mericle MT, Mellgren RL. Participation of the conventional calpains in apoptosis. Biochim Biophys Acta 2002; 1590:16-26.

33. Holski HK, Hawkins C, Zatz M, de Paula F, Biggar D, Alman B, et al. Diagnosis of limb-girdle muscular dystrophy $2 \mathrm{~A}$ by immunohistochemical techniques. Neuropathology 2008;28:264-8.

34. Ermolova N, Kudryashova E, Di Franco M, Vergara J, Kramerova I, Spencer MJ. Pathogenity of some limb girdle muscular dystrophy mutations can result from reduced anchorage to myofibrils and altered stability of calpain 3 . Hum Mol Genet 2011;20:3331-45.

35. Boehm ML, Kendall TL, Thompson VF, Goll DE. Changes in the calpains and calpastatin during postmortem storage of bovine muscle. J Anim Sci 1998;76:2415-34.

36. Dayton WR, Goll DE, Zeece MG, Robson RM, Reville WJ. A Ca ${ }^{2+}$-activated protease possibly involved in myofibrillar protein turnover. Purification from porcine muscle. Biochemistry 1976;15:2150-8.

37.Goll DE, Neti G, Mares SW, Thompson VF. Myofibrillar protein turnover: the proteasome and the calpains. J Anim Sci 2007; 86:E19-E35.

38. Ho CY, Stromer MH, Robson RM. Identification of the $30 \mathrm{kDa}$ polypeptide in post mortem muscle as a degradation product of troponin-T. Biochimie 1994; 76:369-75.

39. Pemrick SM, Grebenau RC. Qualitative analysis of skeletal myosin as a substrate of $\mathrm{Ca}^{2+}$-activated neutral protease: comparison of filamentous and soluble, native, and L2-deficient myosin. J Cell Biol 1984; 99:2297-308.

40. Raynold F, Fernandez E, Coulis G, Aubry L, Vignon X, Bleimling $\mathrm{N}$, et al. Calpain 1titin interactions concentrate calpain 1 in the Z-band edges and in the N2-line region within the skeletal myofibril. FEBS J 2005; 272:2578-90.

41. Borjigin G, Yamamoto S, Sugiyama T, Nishiumi T, Suzuki A. Changes in the immunogold electron-microscopic localization of calpain in bovine skeletal muscle induced by conditioning and high-pressure treatment. Biosci Biotechnol Biochem 2006;70:1249-54.

42. Owen GRH, Meredith DO, Gwynn I, Richards RG. Simultaneously identifying S-phase labeled cells and immunogoldlabelling of vinculin in focal adhesions. $\mathrm{J}$ Miscosc. 2002;207:27-36.
43. Richards RG, Stiffanic M, Owen GRH, Riehle M, Gwynn JAP, Curtis ASG. Immunogold labeling of fibroblast focal adhesion sites visualized in fixed material using scanning electron microscopy, and living, using internal reflection microscopy. Cell Biol Int 2001;2:1237-49.

44. Raser KJ, Posner A, Wang KKW. Casein Zymography: a method to study $\mu$-calpain, m-calpain, and their inhibitory agents. Arc Biochem Biophys 1995;319:211-6.

45. Rabilloud T. Detecting proteins separated by 2D gel electrophoresis. Analyt Chem 2000;72:48A-55A.

46. Pomponio L, Lametsch R, Karlsson AH, Costa LN, Grossi A. Evidence for postmortem m-calpain autolisi in porcine muscle. Meat Sci 2008;80:761-4.

47. Camou JP, Marchello JA, Thompson VF, Mares SW, Goll DE. Effect of postmortem storage on activity of $\mu$ - and m-calpain in five bovine muscles. J Anim Sci 2007;85: 2670-81.

48. Yoshimura N, Murachi T, Heath R, Kay J, Jasand B, Newman GR. Immunogold electron-microscopic localization of calpain I in skeletal muscle of rats. Cell Tissue Res 1986;244:265-70.

49. Kunamoto T, Kleese WC, Cong J, Goll DE, Pierce PR, Allen RE. Localization of the $\mathrm{Ca}^{2+}$ - dependent proteinases and their inhibitor in normal, fasted, and denervated rat skeletal muscle. Anat Rec 1992;232:60-77.

50. Goll DE, Kleese WC, Kumamoto T, Cong JY, Szpacenko A. In search of the regulation and function of the $\mathrm{Ca}^{2+}$-dependent proteinanes (calpains). In: Katumana $\mathrm{N}$, Kominami E editors. Intracellular proteolysis, mechanisms and regulation. Tokyo: Japan Sci Soc Press, 1989, p. 82-91.

51. Goll DE, Thompson VF, Taylor RG, Zalewska T. Is calpain activity regulating by membranes and autolysis or by calcium and calpastatin? Bioessays 1992;14:54956 .

52. Goll DE, Dayton WR, Singh I, Robson RM. Studies of the aactinin/actin interaction in the Z-disk by using calpain. J Biol Chem 1991;266:8501-10.

53. Goll DE, Thompson VF, Taylor RG, Ouali A, Chou R-GR. The calpain system in muscle tissue. In: Wang KKW, Yuen P-W (eds.) Calpain: Pharmacology and Toxicology of Calcium Dependent Protease. Philadelphia, Taylor \& Francis, 1999, p. 127-60.

54. Murachi T, Hatanaka M, Hamakubo T. Calpains and neuropeptide metabolism. In: Turner E (ed.) Neuropeptides and Their Peptidases. Chichester, UK, Ellis Horwood, 1987, p. 202-28.

55. Greenwood JA, Troncoso JC, Costello AC, Johnson GV. Phosphorylation modulates calpain-mediated proteolysis and calmodulin binding of the $200-\mathrm{kDa}$ and $160-\mathrm{kDa}$ neurofilaments proteins. J Neurochim 1993;61:191-9.

56. Eble DM, Spragia ML, Ferguson AG, Samarel AM. Sarcomeric myosin heavy chain is degraded by the proteosome. Cell Tissue Res 1999;296:541-48.

57. Williams AB, Decourten-Myers GM, Fischer JE, Luo G, Sun X, Hasselgren P-0. Sepsis stimulates release of myofilaments by a calcium-dependent mechanism. FASEB J 1999;13:1435-43.

58. Solomon V, Goldberg AL. Importance of the ATP-ubiquitin-proteosome pathway in the degradation of soluble and myofibrillar proteins in rabbit muscle extracts. J Biol Chem. 1996; 271:26690-7.

59. Ouali A, Hernan Herrera-Mendez C, Coulis G, Becila S, Boudjellal A, Aubry L. Sentandreu MA. Revisiting the conversion of muscle into meat and the underlying mechanism. Meat Sci 2006;74:44-58.

60. Sentandreu MA, Coulis G, Ouali A. Role of muscle endopeptidases and their inhibitors in meat tenderness. Trenda Food Scie Technol 2002;13:400-21.

61. Kemp CM, King DA, Shackelford SD, Wheeler TL, Koohmaraie M. The caspase proteolytic system in callipyge and normal lambs in longissimus dorsi, semimembranosus and infraspinatus muscle during postmortem storage. J Anim Sci 2009; 87:2943-51.

62. Dransfield E. Modelling postmortem tenderization. IV: Role of calpains and calpastatin in conditioning. Meat Sci 1993;34: 217-34.

63. Koohmaraie M, Siederman SC, Schollmeyer JE, Dutson TR, Crouse JD. Effects of post-mortem storage on $\mathrm{Ca}^{++}$-depentent proteases, their inhibitor and myofibril fragmentation. Meat Sci 1987;19: 187-96.

64. Veiseth E, Shackelford SD, Wheeler TL, Koohmaraie M. Effect of postmortem storage on $\mu$-calpain and m-calpain in ovine skeletal muscle. J Anim Sci 2001;79:15028.

65. Camou JP, Mares SW, Marchello JA, Vazquez R, Taylor M, Thompson VF, et al. Isolation and characterization of $\mu$-calpain, m-calpain, and calpastatin from postmortem muscle. I. Initial steps. J Anim Sci 2007;85:3400-14.

66. Koohmaraie M, Geesink GH. Contribution of postmortem muscle biochemistry to the delivery of consistent meat quality with particular focus on the calpain system. Meat Sci 2006;74:34-43.

67. Pomponio L, Ertbjerg P, Karlsson AH, Costa $\mathrm{LN}$, Lametsch R. Influence of early $\mathrm{pH}$ decline on calpain activity in porcine muscle. Meat Sci 2010;85:110-4. 